\title{
PROXIMATE COMPOSITION AND HPLC-DAD ANALYSIS OF BIOACTIVE POLYPHENOLS IN LEAFY VEGETABLES CONSUMED IN THE DIET FOUND IN SOUTHERN PART OF BANGLADESH
}

\author{
Puja Ghosh ${ }^{1}$, S. M. Neamul Kabir Zihad ${ }^{1}$, Nazifa Sifat ${ }^{1}$, Razina Rouf ${ }^{2}$, Md. Hemayet \\ Hossain $^{3}$, Shahin Aziz ${ }^{3}$, Md. Saifuzzaman', Jamil A Shilpi ${ }^{1}$ and Shaikh Jamal \\ Uddin $^{1 *}$ \\ ${ }^{1}$ Pharmacy Discipline, Life Science School, Khulna University, Khulna 9208, Bangladesh \\ ${ }^{2}$ Department of Pharmacy, Faculty of Life Science, Bangabandhu Sheikh Mujibur Rabman Science and Technology \\ University, Gopalganj 8100, Bangladesh \\ ${ }^{3}$ Chemical Research Division, Bangladesh Council of Scientific and Industrial Research (BCSIR), Dhaka-1205, \\ Bangladesh
}

KUS: 21/07: 080721

Manuscript submitted: July 08, 2021

Accepted: July 28, 2021

\begin{abstract}
:
Four leafy vegetables, Phyla nodiflora, Amaranthus spinosus, Amaranthus viridis and Chenopodium album usually consumed by the Southern people of Bangladesh. In this study, we tested proximate composition and antioxidant potential of four leafy vegetables and further HPLC content of bioactive polyphenols in the most promising vegetable. The results revealed that they are rich in protein $(12-17 \mathrm{~g} / 100 \mathrm{~g})$, carbohydrate $(10-20 \mathrm{~g} / 100 \mathrm{~g})$ and fibre $(29-44 \mathrm{~g} / 100 \mathrm{~g})$. The ash, glucose, sucrose and xylose contents were found within the ranges of $14-20 \mathrm{~g} / 100 \mathrm{~g}, 35-77 \mathrm{mg} / 100 \mathrm{~g}, 32.79$ $68.72 \mathrm{mg} / 100 \mathrm{~g}$ and $3.79-7.71 \mathrm{mg} / 100 \mathrm{~g}$, respectively. All the vegetables showed a lower content of lipid $(0.73-1.47 \mathrm{~g} / 100 \mathrm{~g})$ and higher moisture content $(81-85 \mathrm{~g} / 100 \mathrm{~g})$. The methanolic extracts of the vegetables were found to possess notable amount of total phenolic (11-60 mg GAE/g), total flavonoid (365-565 mg QE/g) and tannin content (28-49 mg TAE/g). All the samples showed significant DPPH free radical scavenging $\left(\mathrm{IC}_{50} 53-1097 \mu \mathrm{g} / \mathrm{ml}\right)$ and hydrogen peroxide scavenging activity ( $\mathrm{IC}_{50} 41-96 \mu \mathrm{g} / \mathrm{ml}$ ). Out of these four species, $C$. album was found to be the most promising leafy vegetable because of its high protein and fibre content, low lipid content and good antioxidant activities. HPLC-DAD analysis revealed the presence of 3,4-dihydroxy benzoic acid, catechol, vanillic acid, syringic acid, rutin hydrate, p-coumaric acid, trans-ferulic acid, rosmarinic acid and quercetin in C. album. The results of this study provide evidence for the importance of these leafy vegetables in improving the nutritional and health status of Southern rural people of Bangladesh.
\end{abstract}

Keywords: Bangladeshi vegetables, Antioxidant, Proximate Nutritional values; Polyphenols

\section{Introduction}

Leafy vegetables are long admired for their essential biochemical and nutritional importance as they contain good amounts of proteins, fats, carbohydrates, vitamins and minerals as well as provide us with dietary antioxidants (Ebert, 2014; Saikia \& Deka, 2013). Dietary antioxidants from vegetables have been considered beneficial in preventing different chronic diseases and maintenance of good health (Oseni \& Olawoye, 2015). According to numerous epidemiological evidences, consumption of leafy vegetable has protective effect against oxidative damage and reduces risk of cardiovascular disease, diabetes, inflammatory diseases, cancer, alzheimer's, parkinsonism and other chronic diseases

*Corresponding author: < uddinsj@yahoo.com> DOI: http//doi.org/10.53808/KUS.2021.18.01.2107-L 
(Dimitrios, 2006), attributed to different classes of bioactive constituents including micronutrients, polyphenols, flavonoids and sterols (Sree, Joshna, Lakshmi, \& Kumar, 2013). The increase of dietary fresh vegetables intake can reduces the risk of mortality by $20 \%$ (Shetty, Magadum, \& Managanvi, 2013). Native people tend to collect various indigenous leafy vegetables from the wild and their surroundings, and consume them hardly acknowledging their nutritional values and potential health benefits (Asyira, Sarbini, \& Harah, 2017). Therefore, the awareness of consumption of fresh leafy vegetables needs to be promoted among common people to improve their nutritional and health benefits.

In Bangladesh, a huge portion of the total population suffers from malnutrition creating an alarming public health concern. A survey revealed that, the average household consumption of vegetable per person is about $166 \mathrm{~g}$ in Bangladesh, which is well below the minimum required amount (200 g) (Satter et al., 2016). The main concern in Bangladesh is the micronutrient deficiency that is far greater zinc extent than energy malnutrition which makes the general people vulnerable to a variety of health problems. The people of southern coastal region face more food scarcity than other areas of Bangladesh due to soil salinity and lack of cultivable land. They mainly rely on seasonal and native grown leafy vegetables for their daily dietary demand (Zihad et al., 2019). In this study, four coastal leafy vegetables, namely Phyla nodiflora, Amaranthus spinosus, Amaranthus viridis and Chenopodium album were analysed for their nutritional composition and antioxidant potential as well as further HPLC-DAD analysis of bioactive polyphenols in the most promising vegetable. These vegetables are commonly consumed particularly in the southern region of Bangladesh, especially in Khulna, Satkhira and Bagerhat district, not only as food but also as traditional medicine in different ailments. In spite of their local popularity very little scientific knowledge are found regarding their nutritional value, antioxidant potential and their bioactive polyphenols. Thus, the aim of this study is to provide a scientific basis for the dietary and ethnomedicinal utilization of these leafy vegetables.

\section{Materials and Methods}

\section{Collection and preparation of plant samples}

Four common leafy vegetables ( $P$. nodiflora, A. spinosus, A. viridis \& C. album) were collected from Southern part of Bangladesh including Patkelghata, Satkhira and Dumoria of Khulna division. All samples were authenticated by Professor Md. Asaduzzaman, Forestry and Wood Technology Discipline, Khulna University and a voucher number was recorded against each specimen. Plant samples were shed-dried to reduce their moisture content and dried samples were then ground and stored in an air-tight container until used for analysis. The dried powdered sample was extracted by maceration for 5 to 7 days using methanol. Methanol is an ideal solvent for extracting both polar and non-polar bioactive compounds, especially polyphenols. The solvent was filtered and evaporated by means of a rotary evaporator and freeze drying system to obtain crude extract. This crude extract was used of HPLC-DAD detection of polyphenolic compounds.

\section{Proximate composition}

The fat, fibre, ash, and protein contents of the vegetables were determined according to Association of Official Analytical Chemists (2000) on dry weight basis. We determined the protein contents of the vegetables using the Kjeldahl method where the conversion factor for converting nitrogen content to protein content was 6.25 (Kjeldahl, 1883). Fat content was determined by Soxhlet method (Soxhlet, 1879). We determined the fibre content by sequentially extracting with $0.225 \mathrm{~N}$ boiling Sulphuric acid $\left(\mathrm{H}_{2} \mathrm{SO}_{4}\right)$ and $0.313 \mathrm{~N}$ sodium hydroxide $(\mathrm{NaOH})$. To determine the ash content, the samples were left in a muffle furnace at $550^{\circ} \mathrm{C}$ for $6 \mathrm{~h}$ for ignition. The $\mathrm{pH}$ of chopped fresh sample was determined using basic digital $\mathrm{pH}$ meter (Konuk, Afyon, \& Yagiz, 2006). Finally the percentages of moisture, ash, fibre, protein and fat contents were subtracted from 100 yielding the amount of carbohydrate in each sample (Zihad et al., 2019). Sugar contents (mainly hexose, pentose and glucose) were determined by Phenolic-Sulphuric method (Dubois, Gilles, Hamilton, Rebers, \& Smith, 1956).

\section{Determination of antioxidant properties}

Total phenolic, flavonoid and tannin contents of the methanol extracts of the vegetables were determined in our study as measures of main antioxidant components. Folin-Ciocalteu's method was used to determine the total phenolic content where we prepared standard curve with gallic acid (Amorim et al., 2008; Hazra, Biswas, \& Mandal, 2008). We followed the Aluminum trichloride 
Khulna University Studies Volume 18(1): 27-36: 2021

DOI: http// doi.org/10.53808/KUS.2021.18.01.2107-L

colorimetric method to determine total flavonoid content (TFC) of the samples where quercetin was used as the standard (Kariuki \& Mwonjoria, 2013). Finally, total tannin content (TTC) was measured by Folin-Ciocalteu's method where tannic acid was used to construct the standard curve (Amorim et al., 2008).

We evaluated the ability of the vegetable samples to scavenge free radicals through the DPPH (1,1-diphenyl-2-picrylhydrazyl) radical scavenging method (Sadhu, Okuyama, Fujimoto, \& Ishibashi, 2003) and expressed the results as $\mathrm{IC}_{50}$ values. This value denotes the concentration of the sample needed to scavenge $50 \%$ of the free radicals present in the reaction mixture that we derived from the following equation: DPPH scavenged $(\%)=\left[1-\left(\mathrm{Abs}_{\text {sample }} / \mathrm{Abs}_{\text {control }}\right)\right] \times 100$. In addition, we assayed the hydrogen peroxide $\left(\mathrm{H}_{2} \mathrm{O}_{2}\right)$ scavenging potential of the samples following the method described by Ruch, Cheng, and Klaunig (1989). Here the results are also expressed as $\mathrm{IC}_{50}$ values calculated using the following equation: $\mathrm{H}_{2} \mathrm{O}_{2}$ scavenged $(\%)=\left[\left(\mathrm{A}_{\mathrm{o}}-\mathrm{A}_{1}\right) / \mathrm{A}_{\mathrm{o}}\right] \times 100$; where $\mathrm{A}_{\mathrm{o}}$ is the absorbance of the control and $A_{1}$ is the absorbance in the presence of the sample of extract and standard.

\section{HPLC-DAD analysis for estimation of polyphenols}

The $C$. album showed most promising antioxidant and nutrition values and was further analyzed by HPLC to estimate different polyphenols. A rapid separation LC (Dionex UltiMate 3000, Thermo Fisher Scientific Inc., MA, USA) system equipped with an $\mathrm{C}_{18}(4.6 \times 250 \mathrm{~mm} ; 5 \mu \mathrm{m})$ column (Acclaim ${ }^{\circledR}$, USA) was utilized to conduct HPLC analysis using Dionex Chromeleon software (Version 6.80 RS 10) as per Chuanphongpanich and Phanichphant 2006 method (Chuanphongpanich \& Phanichphant, 2006). A gradient system containing of acetonitrile (A), acetic acid pH 3.0 (B) and methanol $(\mathrm{C})$ were used as the solvents using the following elution: 0 to $9 \mathrm{~min} 5 \% \mathrm{~A} / 95 \% \mathrm{~B}, 10$ to $19 \min 10 \% \mathrm{~A} / 80 \% \mathrm{~B} / 10 \% \mathrm{C}$ and 20 to $30 \mathrm{~min} 20 \% \mathrm{~A} / 60 \% \mathrm{~B} / 20 \% \mathrm{C}$. The injection volume was $20 \mu \mathrm{l}$, constant flow rate at $1 \mathrm{ml} / \mathrm{min}$ and the temperature was at $30{ }^{\circ} \mathrm{C}$. The peaks were detected by an UV detector at 280,320, and $380 \mathrm{~nm}$ for 18,24 and $30 \mathrm{~min}$ as well as a photodiode array detector was adjusted to acquisition all the peaks within the range of $200-700 \mathrm{~nm}$. A total of sixteen bioactive polyphenols, namely 3,4-dihydroxy benzoic acid, catechol, catechin hydrate, (-) epicatechin, caffeic acid, p-coumaric acid, gallic acid, kaempferol, myricetin, quercetin, rutin hydrate, rosmarinic acid, syringic acid, trans-ferulic acid, trans-cinnamic acid and vanillic acid was prepared in a solution of methanol to prepare the standard calibration curve. The $C$. album extract solution was also prepared in methanol at a concentration of $5 \mathrm{mg} / \mathrm{ml}$.

\section{Statistical analysis}

The results were presented as mean \pm SD (Standard deviation) and each experiment was performed in triplicates. One way ANOVA followed by Bonferroni's post-hoc test was conducted for statistical analysis.

\section{Results and Discussions \\ Proximate composition}

The moisture contents of the tested leafy vegetables ranged between 81.06 and $85.49 \mathrm{~g} / 100 \mathrm{~g}$ (Table 1). The water content of green leafy vegetables is of great importance when eaten raw as it helps the body to digest them and facilitating absorption of all the nutrients (Lussier, 2010). The studied leafy vegetables showed low amount of fat content ranging between 0.73-1.47 g/100 g of dry weight (DW), with C. album showed the lowest fat content among the four leafy vegetables (Table 1), hence making them ideal diet components for people suffering from obesity, cardiovascular complications and cancer. Dietary fibres has been reported to possesses an essential health promoting role to prevent the development and further advancement of different chronic diseases like diabetes, metabolic syndrome, cardiovascular diseases, inflammatory bowel syndrome and cancer (Soliman, 2019). In this study, we found the amount of dietary fibre present in the leafy vegetable samples in the range between 29.45 and $43.68 \mathrm{~g} / 100 \mathrm{~g}$ DW (Table. 1), with $A$. spinosus showing the highest value $(43.68 \%)$. This study shows that the leafy vegetables is capable of contributing $19-38 \mathrm{~g} / \mathrm{day}$ of recommended dietary intake (RDA) of fibre if a person consumes the equivalent amount of $100 \mathrm{~g}$ dried leaves and, thus, can be regarded as significant sources of dietary fibre for nutrition and disease prevention (Akubugwo, Obasi, Chinyere, \& Ugbogu, 2007). The ash contents of these vegetables 
Ghosh P., Zihad S.M.N.K.., Sifat N., Rouf R., Hossain M.H., Aziz S., Saifuzzaman M., Shilpi J.A. and Uddin S.J. (2021).

Proximate Composition and HPLC-DAD Analysis of Bioactive Polyphenols in Leafy Vegetables Consumed in the Diet Found in Southern part of Bangladesh. Khulna University Studies Volume 18(1): 27-36.

ranged from 14.04 to $19.48 \mathrm{~g} / 100 \mathrm{~g}$ DW (Table. 1). Phyla nodiflora showed the highest ash content $(19.48 \%)$ while the lowest ash content was found in A. spinosus $(14.04 \%)$. Ash content is the unburnable salt reflecting the mineral content in a food (Zihad et al., 2019). Minerals are important dietary element that are playing as key contributors in several biochemical pathways including enzyme activation, oxygen transport and metabolism (Staszowska-Karkut \& Materska, 2020). The high ash content in these leafy vegetables makes them excellent source of dietary minerals for people suffering from malnutrition. According to RDA, every person requires to consume $8 \mathrm{~g} / \mathrm{kg}$ body weight of dietary protein (Lonnie et al., 2018).

Table 1. Proximate composition (g/100 g) dry weight of collected four green leafy vegetables

\begin{tabular}{|c|c|c|c|c|c|}
\hline \multirow{2}{*}{\multicolumn{2}{|c|}{ Nutritional value }} & \multicolumn{4}{|c|}{ Result } \\
\hline & & Phyla nodiflora & $\begin{array}{l}\text { Amaranthus } \\
\text { spinosus }\end{array}$ & $\begin{array}{c}\text { Amaranthus } \\
\text { viridis }\end{array}$ & $\begin{array}{l}\text { Chenopodium } \\
\text { album }\end{array}$ \\
\hline & $83.35 \pm 0.32$ & $80.90 \pm 0.56 f$ & $81.06 \pm 0.35 \AA$ & $85.49 \pm 0.41$ \\
\hline \multicolumn{2}{|l|}{$\mathrm{pH}$} & $7.7 \pm 0.16$ & $7.2 \pm 0.07^{*}$ & $6.87 \pm 0.13^{*}, \#$ & $6.80 \pm 0.14^{*}, \#$ \\
\hline \multicolumn{2}{|l|}{ Lipid \% } & $1.09 \pm 0.61$ & $1.27 \pm 0.7$ & $1.47 \pm 0.5$ & $0.73 \pm 0.61$ \\
\hline \multicolumn{2}{|l|}{ Fiber $\%$} & $37.78 \pm 0.49$ & $43.68 \pm 0.23$ & $29.45 \pm 0.05^{*}, \#$ & $41.47 \pm 0.17^{¥}$ \\
\hline \multicolumn{2}{|l|}{ Ash \% } & $19.48 \pm 1.49$ & $14.04 \pm 0.07^{*}$ & $19.05 \pm 0.06^{\#}$ & $19.33 \pm 1.09 \#$ \\
\hline \multirow{2}{*}{\multicolumn{2}{|c|}{$\begin{array}{l}\text { Protein } \% \\
\text { Carbohydrate \% }\end{array}$}} & $12.15 \pm 0.35$ & $15.60 \pm 1.1^{*}$ & $16.89 \pm 0.55^{*}$ & $15.64 \pm 0.29^{*}$ \\
\hline & & $14.18 \pm 1.07 £$ & $19.99 \pm 0.87^{*}, f^{\prime}$ & $19.19 \pm 1.14^{*}, f^{\prime}$ & $10.87 \pm 0.76$ \\
\hline \multirow{3}{*}{$\begin{array}{l}\text { Sugar } \\
(\mathrm{mg} / 100 \mathrm{~g})\end{array}$} & Glucose & $35.52 \pm 0.69$ & $76.10 \pm 0.76^{*}, f_{0}$ & $75.73 \pm 1.98^{*}, 6$ & $39.03 \pm 0.33^{*}$ \\
\hline & Sucrose & $32.78 \pm 0.61$ & $68.72 \pm 0.45^{*}, \mathbb{E}$ & $68.37 \pm 1.17^{*}, \mathcal{E}$ & $35.75 \pm 1.52$ \\
\hline & Xylose & $3.79 \pm 0.07$ & $7.71 \pm 0.19^{*}, \mathfrak{f}$ & $7.59 \pm 0.19^{*}, \mathfrak{f}$ & $4.07 \pm 0.03$ \\
\hline
\end{tabular}

***Data are expressed as mean \pm SD of triplicate. ${ }^{*} \mathrm{p}<0.05$ vs. Phyla nodiflora, ${ }^{*} \mathrm{p}<0.05$ vs. Amaranthus spinosus, ${ }^{¥} \mathrm{p}<0.05$ vs. Amaranthus viridis, f. $<0.05$ vs. Chenopodium album. Data was analysed by one way ANOVA followed by Bonferroni's test.

In this case, consumption of plant protein contributes to the reduction of mortality risk than animal protein (Song et al., 2016). In our study, the leafy vegetables showed high amount of protein content ranged between 12.15-16.89 g/100 g DW (Table. 1), with P. nodiflora showing the lowest and $A$. viridis showing the highest amount of protein among the tested leafy vegetables. Furthermore, more than $12 \%$ of the calorific value provided by these leafy vegetables is attributed to the protein content, hence, making them good sources of protein (Pearson, 1976). The carbohydrate contents of these leafy vegetables ranged between 10.87-19.99 g/100 g DW (Table. 1). The previous studies of nutritional values (e.g. lipid, protein, carbohydrate, ash and fibre) showed different results from our study for A. spinosus (South African study) (Odhav, Beekrum, Akula, \& Baijnath, 2007), A. viridis (Indian study) (Sharma, Gupta, \& Rao, 2012), C. album (Indian study) (Poonia \& Upadhayay, 2015). This might be due to difference of soil and environmental conditions, such as amount of photosynthetically active radiation, temperature, water availability and analysis technique (Saxena, Venkaiah, Anitha, Venu, \& Raghunath, 2007). In this study, we found the $\mathrm{pH}$ of these leafy vegetables within the range $6.8-7.7$ (Table. 1). It is reported that leafy vegetables contain constituents which are slightly acidic or slightly basic and they are mentioned in the list of slightly acidic or slightly basic foods. Thus, we can say that the selected edible leafy vegetables are as safe food since they don't contain extremely acidic or basic constituents. Diets containing foods that are rich in natural sugars are pivotal to the health of patient with chronic diseases. It is evident that these foods nourishes brain and nervous system, thus delivers benefits ranging from sleep and memory to depression and anxiety. Moreover, natural sugars are essential for glycosylation and help the body in controlling fat and cholesterol. Leafy vegetables contain different types and amount of sugar. The sugar content of the selected four leafy vegetables ranges as glucose 35.53-76.1 mg, sucrose 32.79$68.37 \mathrm{mg}$ and xylose 3.79-7.71 mg per $100 \mathrm{~g} \mathrm{DW}$ (Table. 1). Phyla nodiflora contain the lowest percentage and $A$. spinosus contain the highest percentage of glucose, $A$. spinosus contain the highest percentage $(68.37 \mathrm{mg})$ and $P$. nodiflora contain the lowest percentage of sucrose $(32.79 \mathrm{mg})$, A. spinosus also contain the highest percentage of xylose $(7.71 \mathrm{mg})$ and $P$. nodiflora contain the lowest percentage of xylose $(3.79 \mathrm{mg})$ among these four leafy vegetables. This is the first time study on the sugar contents of these species of leafy vegetables. 


\section{Antioxidant properties of leafy vegetables \\ Total phenolic, flavonoid and tannin content}

The results of TPC, TFC and TTC of methanolic extracts of four leafy vegetables are presented in Table 2. Phenolics are non-nutritive secondary metabolites produced by plants. Though the role of these compounds in plant growth and metabolism is still unclear, they are proven to possess significant health benefit in human and provide protection against different chronic diseases linked to oxidative damage (Delgado, Haza, García, \& Morales, 2009). The TPC of these leafy vegetables ranged between $11.39-59.91 \mathrm{mg} \mathrm{GAE} / \mathrm{g}$. A. spinosus contain the lowest level and P. nodiflora contain the highest level of phenolic content. These levels are higher than those found in the commonly consumed plant based foods from India (0.0-1.2 mg GAE/g raw foodstuff) (Saxena et al., 2007). Among the diverse classes of natural polyphenols, flavonoids are the most widespread group with potent free radical scavenging activity. Generous intakes of dietary flavonoid are beneficial to human health as flavonoids lower the risk of a wide range of chronic diseases including cardiovascular diseases, stroke and some cancers (Saeed, Khan, \& Shabbir, 2012). The total flavonoid contents of the sample vegetables varied considerably between 365 and $564 \mathrm{mg} \mathrm{QE} / \mathrm{g}$, and the order was found to be $P$. nodiflora $>A$. viridis $>C$. album $>A$. spinosus (Table 2). The levels of flavonoid content reported here are higher than the range $(16.72-51.0 \mathrm{mg} \mathrm{QE} / \mathrm{g}$ ) of previous analysis (Ayoka, Ojo, Imafidon, Ademoye, \& Oladele, 2016; Rjeibi, Saad, \& Hfaiedh, 2016). Tannins are another unique class of water-soluble phenolic biomolecules, primarily with astringent property that are well-known for their diverse pharmacological activities with antioxidant potential being the most prominent among them (Vit et al., 2008). The total tannin content of these leafy vegetables ranged between 28.35-48.9 mg TAE/g in which $A$. viridis contain the lowest level and $P$. nodiflora contain the highest level of tannin content.

Table 2. Different antioxidant potential of four green leafy vegetables

\begin{tabular}{|c|c|c|c|c|c|}
\hline $\begin{array}{l}\text { Green leafy } \\
\text { vegetables }\end{array}$ & $\begin{array}{c}\text { TPC } \\
\text { (mg } \\
\text { GAE/g) }\end{array}$ & $\begin{array}{c}\text { TFC } \\
(\mathrm{mg} \\
\mathrm{QE} / \mathrm{g})\end{array}$ & $\begin{array}{c}\text { TTC } \\
\text { (mg } \\
\text { TAE/g) }\end{array}$ & $\begin{array}{l}\text { DPPH free radical } \\
\left(\mathrm{IC}_{50}\right) \mu \mathrm{g} / \mathrm{ml}\end{array}$ & $\begin{array}{c}\mathrm{H}_{2} \mathrm{O}_{2}\left(\mathrm{IC}_{50}\right) \\
\mu \mathrm{g} / \mathrm{ml}\end{array}$ \\
\hline Phyla nodiflora & $59.91 \pm 0.04$ & $564.6 \pm 0.05$ & $48.90 \pm 0.01$ & $1096.48 \pm 1.05$ & $95.49 \pm 0.11$ \\
\hline Amarantbus spinosus & $11.39 \pm 0.09^{*}$ & $365.9 \pm 0.07^{*}$ & $29.90 \pm 0.01^{*}, f_{0}$ & $53.58 \pm 0.39^{*}$ & $41.11 \pm 0.52^{*}, ¥$ \\
\hline Amaranthus viridis & $22.16 \pm 0.07^{*}, \#$ & $393.7 \pm 0.04^{*}$ & $28.35 \pm 0.01^{*}$, & $151.35 \pm 0.23^{*}, \#$ & $68.39 \pm 0.21 *$ \\
\hline Chenopodium album & $16.84 \pm 0.09^{*}$ & $391.7 \pm 0.05^{*}$ & $41.11 \pm 0.04$ & $141.25 \pm 0.47^{*}$,\# & $47.32 \pm 0.42^{* ¥}$ \\
\hline
\end{tabular}

\section{DPPH free radical scavenging assay}

Oxidative stress develops when the amount of free radicals generated from metabolic pathways that results in the emergence of a wide range of pathological conditions in human (McCord, 2000). DPPH free radical scavenging test is a simple, rapid and efficient technique to assay the ability of phytochemicals, foods and beverages to scavenge free radicals and impart anti-oxidant effect (Marinova \& Batchvarov, 2011). Table 2 demonstrated the comparative data of DPPH radical scavenging activity expresses as the $\mathrm{IC}_{50}$ values of the investigated leafy vegetables. The lowest $\mathrm{IC}_{50}$ value and the highest activity were found in methanolic extract of $A$. spinosus followed by $C$. album, $A$. viridis and $P$. nodiflora as compared to ascorbic acid. We observed insignificant correlation between the total phenolic contents of the leafy vegetables and their DPPH free radicals scavenging activity. The total phenolic content generally resembles the antioxidant activity of crude extracts but exceptions have also been seen. Therefore it can be assumed that that there are unknown components present in these leafy vegetables other that polyphenols that contributed a significant part in the observed antioxidant activities, though, among the plant originated antioxidants, polyphenols reside at the top.

\section{Determination of Hydrogen peroxide scavenging assay}

Hydrogen peroxide present inside the cell is usually non-reactive and imparts no ill effect. But when they are converted to hydroxyl radical, they become is toxic and cause oxidative damage. As it happens, hydroxyl radicals are the major contributor to the free radical induced oxidative damage as it adversely affects most of the macromolecules present in living cells altering the habitual redox status (Halliwell, 1991). Through this assay we examined the ability of the selected leafy vegetables to 
convert $\mathrm{H}_{2} \mathrm{O}_{2}$ into water by donating hydrogen and neutralize its toxic effects (Khan, Khan, Sahreen, \& Ahmed, 2012). In our study, these four leafy vegetables showed concentration dependent inhibition of $\mathrm{H}_{2} \mathrm{O}_{2}$ and the results are expressed as $\mathrm{IC}_{50}$ values (Table 2). Hence, lower the $\mathrm{IC}_{50}$, higher the antioxidant activity. The extract of $A$. spinosus showed highest and $P$. nodiflora showed the lowest antioxidant properties manifested by $\mathrm{H}_{2} \mathrm{O}_{2}$ scavenging capacity, thus, possess the ability to prevent the detrimental effects of hydroxyl radical in living system.

\section{Estimation of polyphenols by HPLC}

Polyphenols are one important class of plant constituents due to their ability to scavenge free radicals and prevent oxidative cell damage. As $C$. album showed the most promising antioxidant effects in our study, we performed HPLC analysis to trace polyphenolic compounds and confirmed the presence of 3,4-dihydroxy benzoic acid, catechol, vanillic acid, syringic acid, rutin hydrate, p-coumaric acid, transferulic acid, rosmarinic acid and quercetin (Table 3). Figure 1 represents the HPLC chromatogram exhibited by methanolic extract of C. album.

Table 3: Polyphenolic compounds in the methanolic extract of Chenopodium album identified by HPLC analysis

\begin{tabular}{lc}
\hline \multicolumn{1}{c}{ Polyphenolic compounds } & Contents $\mathbf{( m g / 1 0 0 ~}$ g dry extract) \\
\hline 3,4-Dihydroxy benzoic acid & 11.05 \\
Catechol & 65.65 \\
Vanillic acid & 59.73 \\
Syringic acid & 40.75 \\
Rutin hydrate & 36.19 \\
p-Coumaric acid & 45.95 \\
trans-Ferulic acid & 12.77 \\
Rosmarinic acid & 10.84 \\
Quercetin & 18.43 \\
\hline
\end{tabular}

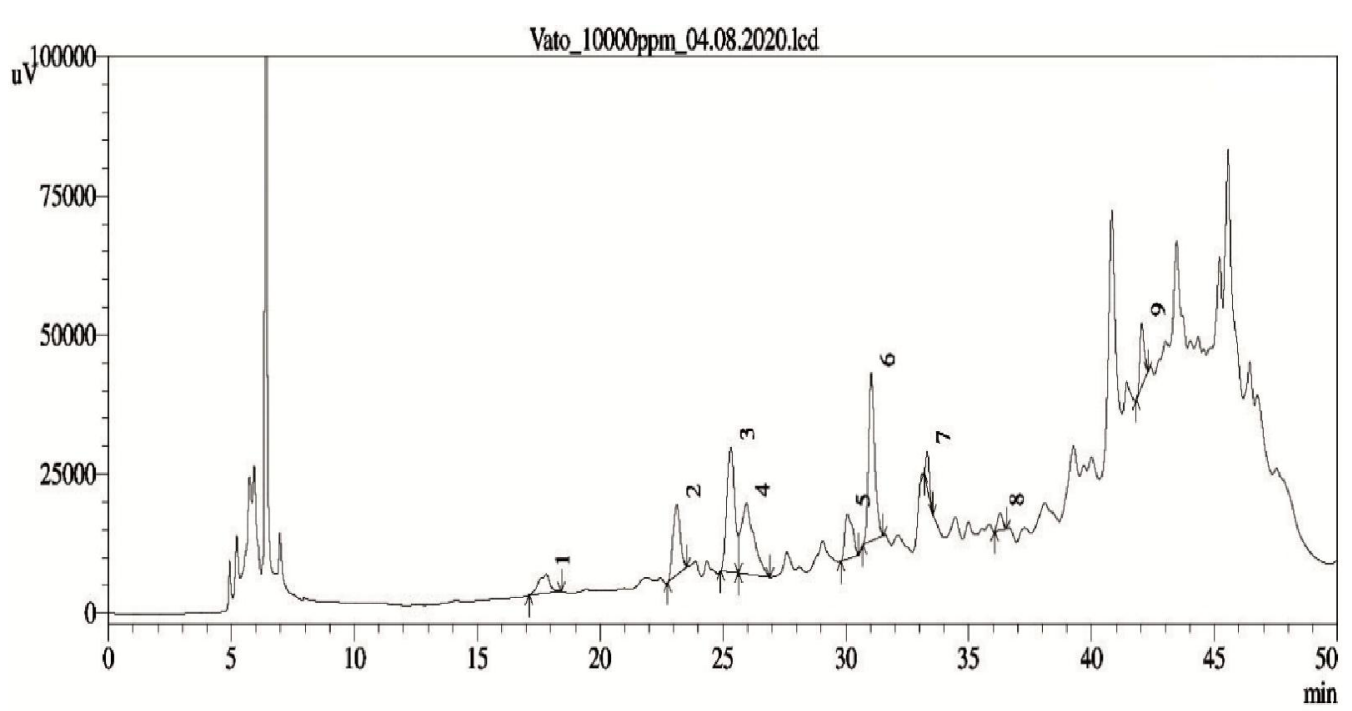

Figure 1. HPLC chromatogram of Chenopodium album extract. Peaks: 1. 3, 4-dihydroxy benzoic acid, 2.catechol, 3.vanillic acid, 4.syringic acid, 5.rutin hydrate, 6.p-coumaric acid, 7.trans-ferulic acid, 8.rosmarinic acid, 9.quercetin.

Out of the nine phenolic compounds (Figure 2) catechol was found in the highest concentration compared to others amounting $65.65 \mathrm{mg} / 100 \mathrm{~g}$ in C. album extract whereas vanillic acid was found $59.73 \mathrm{mg} / 100 \mathrm{~g}$ (Table 3). The identified polyphenols have numerous pharmacological activities. It has been reported that catechol has significant antioxidant potential (Justino et al., 2006) 
and protects melanin from photo and free radical induced damage (Seagle et al., 2005); vanillic acid prevents biomembrane damage caused by free radicals (Tai, Sawano, \& Ito, 2012), improves cognitive impairment and attenuates $A \beta_{1-42}$-induced oxidative stress (Amin, Shah, \& Kim, 2017); $p$-Coumaric acid also possess antioxidant potential (Luceri et al., 2007). These polyphenols have previously been identified in C. album . p-Coumaric acid, Vanillic acid, Ferulic acid, Syringic acid and 3,4-Dihydroxy benzoic acid in C. album extract was identified by HPLC-DAD and mass spectrometry in methanol leaf and flower extracts (Laghari, Memon, Nelofar, Khan, \& Yasmin, 2011), quercetin were identified by flash chromatographic separation of acetone extract (Arora \& Itankar, 2018), rutin and quercetin were identified by HPLC analysis from methanol extract (Chludil, Corbino, \& Leicach, 2008). All polyphenolic constituents found from $C$. album extract are well established antioxidants and free radical scavengers. Thus, they can be held responsible for strong free radical scavenging ability and can be recommended as a food supplement to inhibit $\mathrm{H}_{2} \mathrm{O}_{2}$.induced cellular damage.<smiles>O=C(O)c1ccc(O)c(O)c1</smiles>

3,4- Dhydroxy benzoic acid<smiles>Oc1ccccc1O</smiles>

Catechol<smiles>COc1cc(C(=O)O)ccc1O</smiles>

Vanillic acid<smiles>COc1cc(/C=C/C(=O)O)ccc1O</smiles>

Trans-Ferulic acid

\section{Syringic acid}<smiles>O=C(/C=C/c1ccc(O)c(O)c1)OC(Cc1ccc(O)c(O)c1)C(=O)O</smiles>

Rosmarinic acid<smiles>O=C(O)/C=C/c1ccc(O)cc1</smiles>

p-Coumaric acid<smiles>O=c1c(O)c(-c2ccc(O)c(O)c2)oc2cc(O)cc(O)c12</smiles>

Quercetin

Figure 2. HPLC-DAD identified polyphenols from the methanolic extract of Chenopodium album.

\section{Conclusion}

The present observations revealed the nutritional and antioxidant potential of $P$. nodiflora, A. spinosus, A. viridis and $C$. album, and among these, $C$. album showed the most promising results. Significant amounts of a number of bioactive polyphenols were identified in $C$. album. The consumption of these green leafy vegetables may play a protective role against chronic diseases, especially those mediated by free radical induced oxidative stress, such as aging, cardiovascular diseases, and cancer. However, activity guided isolatioin of individual bioactive components responsible for the observed antioxidant activity, their in vivo effect and specific antioxidant mechanisms need to be revealed by further study. Furthermore, the great variability found in the antioxidant activity of the experimented leafy vegetables needs to be addressed by studying the influence of different factors like maturity stage and harvesting time. 
Ghosh P., Zihad S.M.N.K.., Sifat N., Rouf R., Hossain M.H., Aziz S., Saifuzzaman M., Shilpi J.A. and Uddin S.J. (2021).

Proximate Composition and HPLC-DAD Analysis of Bioactive Polyphenols in Leafy Vegetables Consumed in the Diet Found in Southern part of Bangladesh. Khulna University Studies Volume 18(1): 27-36.

\section{Acknowledgement}

The authors are very thankful to Khulna University Research Cell and Pharmacy Discipline, Khulna University for providing financial support and facilities for carrying out the experimental work.

\section{Conflict of interest}

The authors declare no conflict of interest.

\section{References}

Akubugwo, I., Obasi, N., Chinyere, G., \& Ugbogu, A. (2007). Nutritional and chemical value of Amaranthus hybridus L. leaves from Afikpo, Nigeria. African Journal of Biotechnology, 6(24).

Amin, F. U., Shah, S. A., \& Kim, M. O. (2017). Vanillic acid attenuates A $\beta$ 1-42-induced oxidative stress and cognitive impairment in mice. Scientific reports, 7, 40753.

Amorim, E., Nascimento, J., Monteiro, J., Sobrinho, T., Araujo, T., \& Albuquerque, U. (2008). A Simple and Accurate Procedure for the Determination of Tannin and Flavonoid Levels and Some Applications in Ethnobotany and Ethnopharmacology. Functional Ecosystems and Communities, 2, 88-94.

Arora, S., \& Itankar, P. (2018). Extraction, isolation and identification of flavonoid from Chenopodium album aerial parts. Journal of traditional and complementary medicine, 8(4), 476-482.

Association of Official Analytical Chemists, A. (2000). Official methods of analysis (Vol. 1). Gaithersburg, Maryland: AOAC International

Asyira, S. A., Sarbini, S. N. S., \& Harah, Z. M. (2017). Mineral Content of Five Indigenous Leafy Vegetable from Bintulu Market, Sarawak Malaysia. Journal of Medicinal Herbs and Ethnomedicine, 2, 26-35.

Ayoka, O. A., Ojo, O. E., Imafidon, E. C., Ademoye, K. A., \& Oladele, A. A. (2016). Neuroendocrine effects of aqueous extract of Amaranthus viridis (Linn.) leaf in male Wistar rat model of cyclophosphamide-induced reproductive toxicity. Toxicology reports, 3, 608-619.

Chludil, H. D., Corbino, G. B., \& Leicach, S. R. (2008). Soil quality effects on Chenopodium album flavonoid content and antioxidant potential. Journal of agricultural and food chemistry, 56(13), 5050-5056.

Chuanphongpanich, S., \& Phanichphant, S. (2006). Method development and determination of phenolic compounds in broccoli seeds samples. Chiang Mai J Sci, 33(1), 103-107.

Delgado, M., Haza, A., García, A., \& Morales, P. (2009). Myricetin, quercetin,(+)-catechin and (-)epicatechin protect against $\mathrm{N}$-nitrosamines-induced DNA damage in human hepatoma cells. Toxicology in vitro, 23(7), 1292-1297.

Dimitrios, B. (2006). Sources of natural phenolic antioxidants. Trends in Food Science \& Technology, 17(9), 505-512.

Dubois, M., Gilles, K. A., Hamilton, J. K., Rebers, P. t., \& Smith, F. (1956). Colorimetric method for determination of sugars and related substances. Analytical chemistry, 28(3), 350-356.

Ebert, A. W. (2014). Potential of underutilized traditional vegetables and legume crops to contribute to food and nutritional security, income and more sustainable production systems. Sustainability, 6(1), 319-335.

Halliwell, B. (1991). Reactive oxygen species in living systems: source, biochemistry, and role in human disease. The American Journal of Medicine, 91(3), S14-S22.

Hazra, B., Biswas, S., \& Mandal, N. (2008). Antioxidant and free radical scavenging activity of Spondias pinnata. BMC Complement Altern Med, 8, 63-63.

Justino, G. C., Correia, C. F., Mira, L., Borges dos Santos, R. M., Martinho Simões, J. A., Silva, A. M., ... Gigante, B. (2006). Antioxidant activity of a catechol derived from abietic acid. Journal of agricultural and food chemistry, 54(2), 342-348.

Kariuki, H. N., \& Mwonjoria, J. K. o. (2013). Ethnomedicinal, phytochemical and pharmacological profile of genus Toddalia. Phytopharmacology, 4(2), 259-268.

Khan, R. A., Khan, M. R., Sahreen, S., \& Ahmed, M. (2012). Evaluation of phenolic contents and antioxidant activity of various solvent extracts of Sonchus asper (L.) Hill. Chemistry Central Journal, 6(1), 12.

Kjeldahl, J. (1883). New method for the determination of nitrogen in organic substances. Zeitschrift für analytische Chemie, 22(1), 366-382. 
Konuk, M., Afyon, A., \& Yagiz, D. (2006). Chemical composition of some naturally growing and edible mushrooms. Pakistan Journal of Botany, 38(3), 799.

Laghari, A. H., Memon, S., Nelofar, A., Khan, K. M., \& Yasmin, A. (2011). Determination of free phenolic acids and antioxidant activity of methanolic extracts obtained from fruits and leaves of Chenopodium album. Food chemistry, 126(4), 1850-1855.

Lonnie, M., Hooker, E., Brunstrom, J. M., Corfe, B. M., Green, M. A., Watson, A. W., . . Johnstone, A. M. (2018). Protein for Life: Review of Optimal Protein Intake, Sustainable Dietary Sources and the Effect on Appetite in Ageing Adults. Nutrients, 10(3), 360.

Luceri, C., Giannini, L., Lodovici, M., Antonucci, E., Abbate, R., Masini, E., \& Dolara, P. (2007). pCoumaric acid, a common dietary phenol, inhibits platelet activity in vitro and in vivo. British Journal of Nutrition, 97(3), 458-463.

Lussier, N. (2010). Nutritional value of leafy green vegetables. Retrieved from http://www.helium.com/items/766413-nutritious-value-of-leafy-green-vs-rootvegetables

Marinova, G., \& Batchvarov, V. (2011). Evaluation of the methods for determination of the free radical scavenging activity by DPPH. Bulgarian Journal of Agricultural Science, 17(1), 11-24.

McCord, J. M. (2000). The evolution of free radicals and oxidative stress. The American Journal of Medicine, 108(8), 652-659.

Odhav, B., Beekrum, S., Akula, U., \& Baijnath, H. (2007). Preliminary assessment of nutritional value of traditional leafy vegetables in KwaZulu-Natal, South Africa. Journal of Food Composition and Analysis, 20(5), 430-435.

Oseni, K., \& Olawoye, B. (2015). Underutilized indigenous vegetable (UIV) in Nigeria: a rich source of nutrient and antioxidants-a review. Annals Food Science and Technology, 16(2), 236-247.

Pearson, D. (1976). Chemical Analysis of Foods. (7th Edition ed.). Churchhill Livingstone, London.: J \& A Churchill.

Poonia, A., \& Upadhayay, A. (2015). Chenopodium album Linn: review of nutritive value and biological properties. Journal of food science and technology, 52(7), 3977-3985.

Rjeibi, I., Saad, A. B., \& Hfaiedh, N. (2016). Oxidative damage and hepatotoxicity associated with deltamethrin in rats: The protective effects of Amaranthus spinosus seed extract. Biomedicine \& Pharmacotherapy, 84, 853-860.

Ruch, R. J., Cheng, S.-j., \& Klaunig, J. E. (1989). Prevention of cytotoxicity and inhibition of intercellular communication by antioxidant catechins isolated from Chinese green tea. Carcinogenesis, 10(6), 1003-1008.

Sadhu, S. K., Okuyama, E., Fujimoto, H., \& Ishibashi, M. (2003). Separation of Leucas aspera, a medicinal plant of Bangladesh, guided by prostaglandin inhibitory and antioxidant activities. Chemical and pharmaceutical bulletin, 51(5), 595-598.

Saeed, N., Khan, M. R., \& Shabbir, M. (2012). Antioxidant activity, total phenolic and total flavonoid contents of whole plant extracts Torilis leptophylla L. BMC Complementary and Alternative Medicine, 12(1), 221.

Saikia, P., \& Deka, D. C. (2013). Mineral content of some wild green leafy vegetables of North-East India. Journal of Chemical and Pharmaceutical Research, 5(3), 117-121.

Satter, M. M. A., Khan, M. M. R. L., Jabin, S. A., Abedin, N., Islam, M. F., \& Shaha, B. (2016). Nutritional quality and safety aspects of wild vegetables consume in Bangladesh. Asian Pacific Journal of Tropical Biomedicine, 6(2), 125-131.

Saxena, R., Venkaiah, K., Anitha, P., Venu, L., \& Raghunath, M. (2007). Antioxidant activity of commonly consumed plant foods of India: contribution of their phenolic content. International Journal of Food Sciences and Nutrition, 58(4), 250-260.

Seagle, B.-L. L., Rezai, K. A., Gasyna, E. M., Kobori, Y., Rezaei, K. A., \& Norris, J. R. (2005). Timeresolved detection of melanin free radicals quenching reactive oxygen species. Journal of the American Chemical Society, 127(32), 11220-11221.

Sharma, N., Gupta, P., \& Rao, C. V. (2012). Nutrient content, mineral content and antioxidant activity of Amaranthus viridis and Moringa oleifera leaves. Res. J. Med. Plant, 6(3), 253-259.

Shetty, A. A., Magadum, S., \& Managanvi, K. (2013). Vegetables as sources of antioxidants. Journal of Food and Nutritional Disorders, 2(1), 2.

Soliman, G. A. (2019). Dietary Fiber, Atherosclerosis, and Cardiovascular Disease. Nutrients, 11(5), 1155. 
Ghosh P., Zihad S.M.N.K.., Sifat N., Rouf R., Hossain M.H., Aziz S., Saifuzzaman M., Shilpi J.A. and Uddin S.J. (2021).

Proximate Composition and HPLC-DAD Analysis of Bioactive Polyphenols in Leafy Vegetables Consumed in the Diet Found in Southern part of Bangladesh. Khulna University Studies Volume 18(1): 27-36.

Song, M., Fung, T. T., Hu, F. B., Willett, W. C., Longo, V. D., Chan, A. T., \& Giovannucci, E. L. (2016). Association of Animal and Plant Protein Intake With All-Cause and Cause-Specific Mortality. JAMA Internal Medicine, 176(10), 1453-1463.

Soxhlet, F. v. (1879). Die gewichtsanalytische bestimmung des milchfettes. Dingler's Polytechnisches Journal, 232, 461-465.

Sree, M., Joshna, A., Lakshmi, S. M., \& Kumar, D. S. (2013). A review on South Indian edible leafy vegetables. Journal of Global Trends in Pharmaceutical Sciences, 4(4), 1248-1256.

Staszowska-Karkut, M., \& Materska, M. (2020). Phenolic Composition, Mineral Content, and Beneficial Bioactivities of Leaf Extracts from Black Currant (Ribes nigrum L.), Raspberry (Rubus idaeus), and Aronia (Aronia melanocarpa). Nutrients, 12(2), 463.

Tai, A., Sawano, T., \& Ito, H. (2012). Antioxidative properties of vanillic acid esters in multiple antioxidant assays. Bioscience, biotechnology, and biochemistry, 76(2), 314-318.

Vit, K., Katerina, K., Zuzana, R., Kamil, K., Daniel, J., Ludek, J., \& Lubomir, O. (2008). Condensed and Hydrolysable Tannins as Antioxidants Influencing the Health. Mini-Reviews in Medicinal Chemistry, 8(5), 436-447.

Zihad, S. M. N. K., Gupt, Y., Uddin, S. J., Islam, M. T., Alam, M. R., Aziz, S., .Sarker, S. D. (2019). Nutritional value, micronutrient and antioxidant capacity of some green leafy vegetables commonly used by southern coastal people of Bangladesh. Heliyon, 5(11), e02768. 